\title{
Development of positive psychological capital at a Roma Student College
}

\author{
ARANKA VARGA ${ }^{*}$ (D), FANNI TRENDL and KITTI VITÉZ
}

University of Pécs, Faculty of Humanities, Institute of Education Sciences, Ifjúság útja 6, H-7624, Pécs, Hungary

\section{THEMATIC ARTICLE}

Published online: October 30, 2020

(c) 2020 The Author(s)

\section{ABSTRACT}

The aim of our study is to present different kinds of obstacles that hindered the successful educational progress of our Roma university student interviewees from disadvantaged backgrounds. The theme is equality and equity, which is examined in the context of inclusion, empowerment, resilience and intersectionality (Varga, 2017), and to investigate their effect on positive power of performance, the positive psychological capital. Our research sample consists of the community members of the diverse Roma Student College of Pécs. The studied university students are considered resilient (Masten, Herbers, Cutuli, \& Lafavor, 2008), as they have overcome the hardships of their family background and learn in higher education. Our study gives an analysis of 27 life-path interviews conducted in 2017. In these life-path interviews, we have found the external sources of resilience: supportive families, models of friends and siblings, and teachers' support as well. The intrinsic changes of personality have been prominent in the narratives, which could often balance out the negative effects with the positive psychological capital. The "building blocks" of this capital (Luthans et al., 2007) can be detected at common points in walk of life interviews, such as positive self-image, motivation, goal-orientation, and conscious planning. The positive role of the Roma Student College community appeared in their narratives as a strikingly relevant factor, from which we can assume that the shared development of different "capital types" results in investments in the interiorization process of individual members.

\section{KEYWORDS}

Roma Student College, positive psychology, resilience, empowerment

\footnotetext{
"Corresponding author. E-Mail: varga.aranka@pte.hu
} 


\section{INTRODUCTION}

The establishment of the Roma Student College Network ${ }^{1}$ was a key education policy for the betterment and empowerment of the Hungarian Roma (Forray ed., 2015). The network of 11 student colleges - funded by either Higher Education or Church - spreads across the country, supporting almost 300 disadvantaged, mainly Roma university students. ${ }^{2}$ It is important to consider what difficulties these young adults have encountered during their career and how they have overcome as the first generation from their families who entered higher education. Former studies confirmed (Rayman \& Varga, 2015) that accumulation and conversion of different capitals (cultural, social, positive psychological) is essential for a successful academic path. In this study we examine the accumulation of capitals by the analysis of life path interviews.

The establishment of Roma Student Colleges, their inclusion in the Higher Education Act and their prominent support indicates that it must create conditions conducive to real equal opportunity for students in order to compensate for injustices in society. The diverse service system of colleges promote inclusion with the aim of ensuring that students from socially disadvantaged backgrounds profit from the benefits offered by higher education (Trendl, 2015).

Some of the challenges of accessing benefits are easy to handle. Examples include the lack of money, which can be compensated by a scholarship, or the difficulty with administrative paperwork when entering higher education, which can be solved with the help of a more experienced student partner. However, the lack of access to goods is often caused by a lack of processes whose complexity requires a more complex and long-term offset (Forray, 2014, 2016). There is an underdevelopment of learning and key competences among Roma Student College students, a byproduct of public education (Jenei \& Kerülö, 2016), as well as the lack of cultural capital due to settlement or social disadvantage. It is also characteristic that both the learning environment that is increasingly divergent from family socialization and the feeling of belonging to a minority (stigmatized) group have a significant and often negative effect on the self-esteem of students and these may ultimately hinder their successful progress. Student Colleges with fair interventions strive to break down inequality and offset them (Jancsák, 2016; Varga, 2015a).

Most Roma students are in a situation that is described by the literature as a phenomenon of intersectionality (Cserti-Csapó \& Orsós, 2013; Óhidy, 2016). The complexity created by intersectionality is caused by a combination of two types of inequality. In a permanent situation, there are several categories of inequality that interact with each other thus creating a new social category, in which different causes of oppression cannot be separated (Asumah \& Nagel, 2014; Sebestyén, 2016; Óhidy, 2016). Intersectionality is the sum of the various capital gaps (financial assets, cultural, social, and symbolic capital) and negative social perceptions (latent or discriminatory) of each student in Roma Student Colleges, which reinforce each other.

Bourdieu (1978) drew attention to the process of creating and sustaining a lack of capitals in the 70s. According to his Theory of Capital, the school system becomes a legitimate tool for the reproduction of social inequality by ignoring the capital transfer processes which result from the

\footnotetext{
${ }^{1}$ The criteria and operating principles for the establishment of Roma Student Colleges are set in Section 54 of Act XIV of 2011 on the CCIV.

${ }^{2}$ The current state of the Roma Student College Network is presented in a thematic issue of the Journal Romology, published in Spring, 2018. Available at: http://romologiafolyoirat.pte.hu/wp-content/uploads/2018/07/romologia_15. pdf.
} 
social situation of the family. In addition to the lack of financial capital, the difference in the possession of cultural and symbolic capital embedded in the family's disposition, as well as their ability to invest this capital in the educational progress of the child, is decisive (Bourdieu, 1978). Coleman's Bourdieu theory was complemented by social capital, emphasizing the importance of capital available in social network and convertible in the school system. In the recent decades, attention has focused on positive psychological capital and it has been proven that its strength significantly increases individual and organizational performance (Luthans et al., 2007). One of the building blocks, based on Bandura (1998), is called self-efficacy; when an individual can mobilize his or her motivation, abilities, and acts to successfully complete a difficult task. Another element is "hope" when you can set goals and achieve them by hard work, you are capable of changing the path to success. This also requires resilience (flexibility) based on Masten (2001) and Masten, Herbers, Cutuli, and Lafavor (2008) which means not only coping with difficulties but also the resulting positive power. Seligman (1998) completed this notion with the ability to remain optimistic; when an individual attributes positive event to his or her intrinsic qualities, while negative events are explained by external and unexpected reasons and at the same time, this person realistically knows what she or he can achieve by increasing his or her goals, actions and effectiveness. The interaction of these four building blocks of positive psychology as an internal force contributes to overcoming difficulties and to a successful life path. Based on Yosso's concept, Óhidy used the notion "Roma social capital" for those students who can be successful even in a non-supportive environment because of the community cultural wealth (2016).

Another factor that plays a role in intersectionality is the negative perception of Roma communities which is embedded in different social cohabitation strategies and has a fundamental impact on the attitude and identity of a person belonging to such a minority group (Jancsák, 2016; Varga, 2015b). It is also important to know that belonging to a stigmatized group (= judged, stigmatized by others) affects individual self-esteem, emotional well-being. If a given group we belong to is perceived negatively, then we start doubting ourselves, too (low self-esteem). This creates negative emotions which permeate all aspects of life and threaten both physical and emotional well-being (Smith, Mackie, \& Claypool Heather, 2016). In other words, stigmatization resulting from prejudices also affects elements of personal identity (e.g., self-esteem) and not just social identity. One "symptom" of this are the form of attitudes towards social identity, which is more of a defense mechanism (e.g., becoming unwilling to assimilate so as to protect its self-esteem). The importance of positive psychological capital makes it essential to counteract negative external effects and strengthen self-esteem.

Based on the aforementioned researches our study focuses on how Roma Student College members accumulated different forms of capitals during their life-paths. The establishment of Roma Student College and the identification of its target group were fundamentally influenced by the fact that social disadvantages and belonging to a Roma community in Hungary form often one in the same. Several researches have shown in the past decades that social disadvantages in Hungary are exacerbated by the negative social prejudice associated with the Roma minority group (Forray \& Hegedüs, 2003; Forray \& Pálmainé, 2010; Cserti-Csapó \& Orsós, 2013). Educational focus studies have provided data that failure at school is a common phenomenon amongst disadvantaged and Roma students, so educational issues related to these characteristics cannot be separated (Fehérvári, 2015; Híves, 2015). When discussing the 
educational situation of the Roma, the researchers have been reporting gradual improvements, but it was also found that the gap has not narrowed from the non-Roma population (Havas, Kemény, \& Liskó, 2002; Kemény, Janky, \& Lengyel, 2004; Zolnay, 2015). This is also reinforced by the fact that Roma students are more likely to be early school leavers or to choose shorter education paths. (Liskó, 2003; Mártonfi, 2013, 2015) Today, more research has pointed out that the deterioration of Roma/Gypsy students' school performance is exacerbated most by the coexistence of poverty and ethnic segregation (Kertesi \& Kézdi, 2012).

\section{Research questions and method}

All members of the Roma Student College members ( 32 people) were interviewed in the autumn of 2017, and 27 interviews were used for the analysis presented in the study. The in-depth interview includes the Roma Student College members' life history, family and school memories, as well as their plans. The interview questions were aimed at exploring the external and internal effects and factors of the students' lives that can be linked to their successful educational progress. The interviews were processed qualitatively, with narrative content analysis - using a pre-defined code system. We used the variable data of the interviewed students for the analysis of the interviews: their age, place of residence, their undertaken identity, their social status, time of their college membership, their higher education degree, and their grades, which were treated as independent and dependent variables in the analysis.

The following questions were in focus:

1. How did Roma Student College members' accumulation of capitals change?

2. Which capitals are essential for building and sustaining resilience - against difficulties - for elaborating successful life-paths?

Our hypothesis is that typical life situations will be presumably found in the life-paths of the Roma Student College members, which influenced their accumulation of capitals and resilience.

\section{The examined group}

Almost half (11 persons) of the Roma Student College students who were interviewed are characterized by intersectionality. A further eight people identified themselves as Roma, but there were not any documents related to the legal criteria for the disadvantaged status. Overall, $70 \%$ of the respondents are Roma. Six College students confirmed their social disadvantaged status but did not classify themselves as Roma. Two members of the community do not belong to any of the aforementioned categories but have joined the Student College because of their different disadvantages (e.g., broken home) seeking a supportive background.

The residency of the college students is also varied: six of them come from Pécs, 9 from small towns and 11 from small settlements; this distribution also signals social disadvantages. The examined college community is diverse in terms of their family background.

Their common feature is that, without exception, they have disadvantages which have made their school career more difficult. Two thirds of the respondents (18 people) live in a dormitory. Students are from five faculties of the University, doing five types of higher education (Table 1). We hope to find forms of support which could apply to all participating students in this seemingly diverse community on their way to a successful academic path. 
Table 1. Differences in training levels among the members of the study group $(N: 27)$

\begin{tabular}{lccc}
\hline Faculty & Persons & Level & Persons \\
\hline Faculty of Medicine & 1 & VET $^{\mathrm{a}}$ & 2 \\
Faculty of Humanities & 11 & $\mathrm{BA} / \mathrm{BSc}$ & 9 \\
Faculty of Information Technology & 4 & $\mathrm{MA}$ & 1 \\
Faculty of Arts & 1 & Undivided Training & 1 \\
Faculty of Sciences & 10 & Teacher training & 14 \\
\hline
\end{tabular}

${ }^{a}$ Higher Level Vocational Training - A two-year form of Higher Education.

\section{RESULTS AND DISCUSSION}

\section{The development of resilience and positive psychology}

Interviews have been conducted previously among the students of the examined Roma Student College and were analyzed in comparison with a control group of high social status (Rayman \& Varga, 2015). The focus of the analysis was on the difficulties that surround schooling and on coping strategies that could address them. However, the supporting family background managed to solve most of these difficulties. Roma students who came from disadvantaged backgrounds to higher education highlighted significantly more difficulties in connection with their school career. The school and external organizations primarily compensated for these difficulties. Although there were plenty of issues on campus, supporters neutralized their impact, and were able to outweigh the disadvantages. All this proved that in each institution and space the right amount of inclusiveness helped the disadvantaged to become even more resilient in each institution and space.

It is also remarkable that, in addition to financial difficulties, three quarters of students mentioned that they have a highly motivating family background. Parents, relatives who tried to create the conditions even if they were unable to help with studies and considered further education important. The results confirmed the importance of school collaboration with the family, which is essential for joint efforts to motivate learning. There is an apparent pattern amongst families of Roma Student College members - older siblings or parents - whose following shows an extraordinary support in their narratives (Table 2).

Table 2. The details of the study group's life paths (N:27)

\begin{tabular}{|c|c|c|c|c|c|}
\hline \multirow[b]{2}{*}{ Topic } & \multirow{2}{*}{$\begin{array}{c}\text { Individual } \\
\text { disadvantage } \\
\\
\text { (e.g., } \\
\text { dyslexia, } \\
\text { etc.) }\end{array}$} & \multicolumn{2}{|c|}{ Family disadvantage } & \multicolumn{2}{|c|}{ Family advantage } \\
\hline & & $\begin{array}{c}\text { Traumatizing } \\
\text { Event (Deviance/ } \\
\text { Family Tragedy) }\end{array}$ & $\begin{array}{l}\text { Poor, orphan, } \\
\text { many brothers, } \\
\text { uneducated/ } \\
\text { illiterate parents, } \\
\text { foster children }\end{array}$ & $\begin{array}{l}\text { Family member(s) } \\
\text { helping with } \\
\text { studying, } \\
\text { continuous } \\
\text { motivation coming } \\
\text { from home }\end{array}$ & $\begin{array}{l}\text { Siblings as } \\
\text { role } \\
\text { models }\end{array}$ \\
\hline Persons & 6 & 12 & 22 & 20 & 9 \\
\hline
\end{tabular}


One of the reasons behind this is that the family pattern has enhanced their self-efficiency as a role model; they have seen someone in a similar position to them and despite hardships achieved success through their efforts. "I have a bigger brother who went to the University of Pécs and has done the masters in Pest. So there is a relative tying me to the university, because I have a brother 5 years older than me, but our parents did not go to school and I think somehow that generation created a gap, but now we do enjoy studying" (Roma Student College member). All of this was a motivational force, which helped to build confidence (elements of positive psychology and self-efficiency) in their own abilities (Bandura, 2008). It is also important to see that social comparison in the minority group works in the opposite way as comparison to a majority group. Self-esteem of those belonging to a minority group is not reduced, but rather increases by personal comparison to those with outstanding performances in their own group. In the case of a minority group, the individual shares the success of another - counterbalancing the selfconfidence-reducing effect of stigmatization (Brewer \& Weber, 1994).

Based on researches resilient students are often limited by their disadvantages that hinder their success, but they still manage to be successful in their school careers. To do this, it is essential to have protective conditions that can counterbalance risk factors in order to successfully adapt to difficult conditions develop resilience and helped to accumulate different forms of capitals. Low socio-economic status (social disadvantage, negative social perception) and traumatic life events are all external risk factors. The external protective conditions (family, school, peer group) are available in the system of agencies of socialization (Homoki, 2016; Masten et al., 2008; Ceglédi, 2012).

The members of the examined group in our study can be considered resilient, as they have successfully moved forward in public education and are currently studying in higher education. Based on macro statistical data, disadvantaged mostly Roma students in Hungary are underrepresented in Higher Education (Arató \& Varga, 2015). Traumatizing life events like for instance, are dominant (12 person) in the interviews, and even if they are processed to some extent, our students still carry them like packages.

One of the students mentioned the following:

"Then I told her that my mother was drunk, I woke up at five in the morning, so that is why I did not do good on the test.... However, when the Professor asked for the class money, I lied because I was like, I can save up that much money somehow, I will give you the money eventually. I did not want to tell you why I didn't have the money because I didn't want to tell you what was going on at home." (Roma Student College member)

Their life stories also include possible coping strategies, which shows immense internal strength, struggle, perseverance, and willingness. External supporters appeared who were able to establish confidential relationship with these young students in almost every case examined. The number of those who did not talk about their difficult financial circumstances - such as parents' lack of education, unemployment or orphanage - was small (Table 2).

Based on the interviews of the Roma Student College members, this community is similar to a family relationship or friendship and as a reference group provides obtainable patterns for learning motivation. So being part of a community such as a Roma Student College can also contribute to the strengthening of positive psychological capital. This supportive inner - personal and communal - force is complemented by the cultural and social capital available in the services and network of the Student College. "You can turn to the community and their members 
with anything. And the core that has developed within the community is, I think, so precious and that it is very, very important. And this has become a fix point in my life, at least for a while." (Roma Student College member).

External influences such as fellow students and teachers appeared in the 2017 narratives of Student College member interviews (Rayman \& Varga, 2015), who either hindered or strongly supported the examined members during their years at school. Table 3 shows that students recalled equal proportions of persons who supported them and those who hindered them at the time that they were in elementary school.

However, during high school, the cases of persons who hindered progress were significantly reduced while all the participants were able to recall predominantly positive experiences. There are many explanations behind this change: the temporal distance of remembrance, age characteristics, homogeneous studying environments in primary school, etc. It is important to emphasize that the personal level and the longer - often-permanent - effects were the decisive ones in the supportive relationships mentioned during high school education. This statement is of particular importance to teachers who have also become a role model for the supported student - even in terms of career choice.

Every fifth student spoke of an exclusionary event related to poverty or being Roma during primary school. The recalled stories left a profound negative effect on Roma Student College members' self-confidence and dignity (One of the turning points in elementary school was when one of the PE teachers called me" little black", "We couldn't play with toys in pre-school because we were Gypsies", "There teachers told me that nothing would become of me, I will become a con, yes"). These narratives represent different ways of recalls "minimizing", exemption, shame, identification, anger, and the burden of proof.

Table 4 depicts the advancement in higher education, when the Student College members mostly talked about how they made their own decisions, spite their preliminary fears. We can see the strengths of psychological capital in this: these traits: self-efficacy (setting goals and investing in the paths towards the goal), optimism (in spite of external difficulties, the achievement of success - entering into higher education - is associated with one's own personal decisions, features and actions).

Table 3. The details of the Roma Student College members' life paths ( $N: 27)$

\begin{tabular}{cccccc}
\hline & \multicolumn{2}{c}{ Primary school } & & \multicolumn{2}{c}{ Secondary school } \\
\cline { 2 - 3 } \cline { 5 - 6 } Topic & $\begin{array}{c}\text { Disadvantage }- \\
\text { or student }\end{array}$ & $\begin{array}{c}\text { Advantage - Support } \\
\text { teacher and/or } \\
\text { student }\end{array}$ & & $\begin{array}{c}\text { Disadvantage - } \\
\text { Bullying teacher and/ } \\
\text { or student }\end{array}$ & $\begin{array}{c}\text { Advantage - } \\
\text { Support teacher } \\
\text { and/or student }\end{array}$ \\
\hline Persons & 15 & 15 & & 2 & 23 \\
\hline
\end{tabular}

Table 4. Progress in Higher Education ( $N: 27)$

\begin{tabular}{cccccc}
\hline & \multicolumn{5}{c}{ Motivation for entering Higher Education } \\
\cline { 2 - 6 } Topic & $\begin{array}{c}\text { Support from } \\
\text { a teacher }\end{array}$ & $\begin{array}{c}\text { Parental } \\
\text { support }\end{array}$ & $\begin{array}{c}\text { Encouragement coming } \\
\text { from a friend }\end{array}$ & $\begin{array}{c}\text { Intrinsic } \\
\text { motivation }\end{array}$ & $\begin{array}{c}\text { Following in a } \\
\text { Sibling's Footsteps }\end{array}$ \\
\hline Persons & 10 & 12 & 5 & 18 & 6 \\
\hline
\end{tabular}


Students also expressed their prior fears about further education. This consisted primarily of material burden, higher education being unimaginable, which was the result of the lack of cultural and social capital in an uneducated family environment. This kind of fear did not appear in narratives where there was a sibling role model in the family or, to a lesser extent, to those who received strong friend or teacher support. In other words, role models that enhance personal identity (self-efficiency) became an important supportive force (My goal is to become a teacher because I really like to deal with kids and people. And not only to give them academic knowledge, but I'm also thinking about kids wanting to break out and give them spiritual support. Just like Mrs. Gabi." (Roma Student College member). It is also important that around half of the Roma Student College members have stressed that their family has done their best to help further education; "I have a bigger brother who went to the University of Pécs and has done the masters in Pest. So, there is a relative tying me to the university" (Roma Student College member).

Our study specifically focused on the internal factors that influence the life of the Roma Student College members and the personal side of coping with difficulties. We have seen that almost half of the students recalled traumatic events at some stage in their life, in addition to their social disadvantage. In addition to external support, the internal factors of their resilience are essential for successful coping with difficulties, which several narratives have exemplified. These included conscious and long-term career planning, motivation, self-confidence and a positive perception of the future, which all appeared in the interviews at an extremely high rate. All the above-mentioned internal features constitute the positive psychological capital characteristic of Roma Student College members. Self-confidence, which increases self-efficiency, was prominent in the interviews. Decisively the "hope" for changing their difficult circumstances is the positive motivational force that we could grasped in most interviews, which motivates college students to accomplish their goals (willpower), and which were accompanied by achieving goals (waypower) in their narratives (Luthans, Luthans, \& Luthans, 2004). It is important to note that some of these attributes were assigned to an external support person (parent, friend, and teacher) at an earlier stage of students' life but most of them became internalized by now.

\footnotetext{
"Although it would feel good to get back at them, look at me now, who became what. Because there is a classmate from that time who is not a Gypsy, and they all had high hopes for him and now he is in prison. And now I' would just get back at them, who ended up in jail and who has gone how far" (Roma Student College member). These lines can serve as an example for the standardization of sequence of events, which appeared in many interviews. In several interviews, we could see how the narrators had chosen various strategies against different difficulties, most of which were exclusion or failure at school. However, the conscious will to change and the intention of proving themselves to the social environment is a common point.
}

In most cases, Roma Student College members say a change, best described as an internal impulse, happened in the beginning of their senior year, but there is always a person in school who has provided decisive support in this process. The external person usually had some kind of talent-development activity to reinforce their confidence (self-reinforcing mechanism) through direct feedback of his or her personal value (talent), direct and immediate success in an environment (school) where socially disadvantaged students are usually lagging behind.

Talent management in this sense has a positive Pygmalion effect. The Pygmalion effect or "self-fulfilling prophecy" phenomenon was first discovered in classroom relations (Rosenthal \& 
Jacobson, 1968). Studies have shown that a teacher's negative or positive attitude towards a student, regardless of the student's ability, motivation, knowledge, etc. - has a decisive impact on student performance. Talent management - in contrast to a "catching-up" approach for disadvantaged students - strengthened the personal elements of emotional intelligence in Student College members. Enhanced the self-consciousness (knowledge of our own internal state, preference, resource and intuition) and the ability to self-regulate and motivation (Goleman, 2002). The personal elements of emotional intelligence can recognize the elements that are essential for the development and maintenance of resilience and are part of the positive psychological capital. That is why it is important to build on talent development in Roma Student Colleges (Trendl \& Varga, 2018).

Interviews confirmed that an equitable environmental support with a positive pedagogical focus had an impact on individual development. They managed to achieve long-term results if they were able to reinforce the values inherent in the individual with external influences and develop the ability to shape their own fate. One of the important characteristics of resilient students is that they have played an active role in the development of their own lives.

\section{Possibilities of developing empowerment}

The interrelations of resilience and positive psychology capital multiplies the strengthening effect of the two processes when the individuals become more and more active and in addition to his/her own interest, he or she also considers the interests of the community. Empowerment, identified in the field of social policy and social psychology, is the process of gaining power, during which the individual and later the community becomes capable of self-determination and formulation of their common objectives. The individuals recognize their position of power and have the courage to use this power for the sake of the community. They also have the power to change their own and their community's social inequality situation and turn their life around for the better (Adams, 2003; Lakatos, 2010). During the development of empowerment, the individuals gradually recognize how power structures affect their circumstances in a negative way and how they can use support tools to bring about change, acquire elements of competence and organize community activities.

The phenomenon of empowerment in educational context, linked to the concept of inclusivity and resilience, creates a new perspective. This more complex approach highlights the necessity of the conscious development of individual empowerment. With the aim of developing empowerment, the inclusive environment becomes more interactive, thus providing supportive conditions for the individual. The inclusive environment that builds upon self-creation and cooperation, presupposes the goal of achieving the resilience of people within it. The positive experiences of cooperation (gaining motivation and competence), contribute to the inner integration and maintenance of empowerment on a personal level (Varga, 2017).

Consequently, empowerment is a process (Fig. 1), the first stage of which takes place on the individual level and extends from self-respect to the formation and maintenance of resilience. This leads to the evolvement of a sense of responsibility for the community, actual action and resulting changes (Travis \& Bowman, 2015). Community empowerment also has an impact on resilience, as bearing responsibility for others encourages self-help mechanisms (Varga, 2015a).

In case of the observed Student College, the commitment of the Roma community and the related social responsibility as the main element is the highest degree of empowerment. The starting point is a positive attitude towards one's own identity and the establishment of self- 


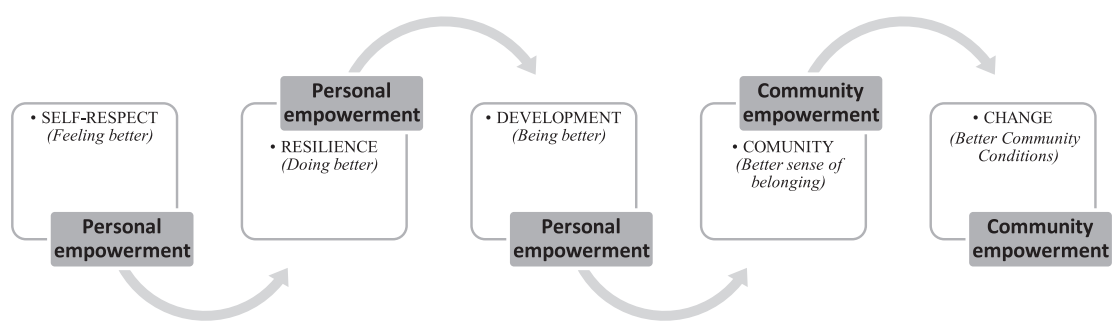

Fig. 1. The framework of personal and community empowerment (Travis \& Bowman, 2015)

esteem. The diversity of minority attitude appears in different ways among the members of the Student College (19 people), belonging to the Roma community (Table 5). Barely half of the students experience a strong sense of identity in their family (e.g., parents). Also, they rarely mentioned preserving traditional Roma habits or using Roma language at home. In most cases, the question of identity has not yet become relevant for children who attend elementary school. They considered public education neutral in relation to their identity. The individuals do not feel discriminated based on their identity, since the hegemony of the majority culture is considered natural by them, for example in educational contexts. As a consequence of implicit impacts on the individuals, such as colorblindness, the sense of assimilation grows stronger in them. Later this sense gets broken down every time the individuals are discriminated against because of their physical racial features ("So I had friends, but they made fun of me anyway. Because of my skin, because I'm a Gypsy" - Roma Student College member). Since they have formed an ethnocentric identity in the school system, they typically do not have the means to respond constructively, either based on positive identity or self-defense mechanism (Arató, 2012).

This mechanism is supported by the life path interviews, as we encountered one or two similar examples to the ones mentioned above. However, in the narratives, the Roma Student College members say the issue of identity mainly appears during high school and it is associated with implicit or explicit racist attitudes. Also, nearly all of them could list examples of discrimination based on their race but some of these stories were affecting their environment rather than them. This mechanism typically appears in researches dealing with the strategies of a minority shifting towards assimilation, which ultimately contribute to the maintenance of racism (Arató, 2012).

It is also worth mentioning that two-third of the respondents emphasized the opportunity to embrace their Roma identity as the following example shows; "Now, it feels so much better to do so in the special College because it is ordinary and accepted here" - Roma Student College member as one of the greatest virtues of the Roma Student College. Social psychological studies of empowerment have demonstrated that the positive experience of group identity reinforces the sense of belonging to a group, which is the first level in the development of empowerment (Travis \& Deepak, 2011).

Considering the duration of the membership, it is apparent that the newer members are more "identity-neutral", who do not neglect their minority identity but consider it a barely an indeterminant factor. In their case, it is more noticeable that they are performing exceptionally in other areas (e.g., learning) as a form of compensation. The "avoidant" attitude can also be 
Table 5. The life path details of the studied group - identity ( $N: 19)$

\begin{tabular}{|c|c|c|c|c|c|c|c|c|c|c|}
\hline \multirow[b]{3}{*}{ Mentioned topics } & \multicolumn{7}{|c|}{ Relation to Roma identity } & \multirow{2}{*}{\multicolumn{2}{|c|}{$\begin{array}{c}\text { Discrimination of } \\
\text { Roma group }\end{array}$}} & \multirow{3}{*}{$\begin{array}{l}\text { The positive identity } \\
\text { forming role of WHSZ }\end{array}$} \\
\hline & \multicolumn{2}{|c|}{ Family } & \multicolumn{3}{|c|}{ Public education } & \multicolumn{2}{|c|}{ Individual } & & & \\
\hline & Strong & Weak & Positive & Neutral & Negative & Positive & Neutral & School & Labor market & \\
\hline Number of people & 8 & 8 & 2 & 13 & 1 & 14 & 5 & 10 & 2 & 13 \\
\hline
\end{tabular}


observed, which is more negative than identity-neutrality and often appears in the form of denial. In this case, the compensation mechanism is prominent as well, as one of them emphasized; "It has always been emphasized I should be aware of the fact that compared to others I always have to go the extra mile for the exact same thing. I've always been a little angry about this. I think it is unfair that because I'm a Gypsy, or perhaps someone else, I have to do more to prove myself." (Roma Student College member).

However, the importance of belonging to the community of young people of similar background is expressed by almost everyone, which is the sign of the strength of their social identity. Some members, who have been at the Student College for two years or longer, are somewhat more conscious of their Roma identity, and they are also involved in shaping the future values of the Student College community.

One of the ways to inspire empowerment in the Roma Student College is to support children by doing volunteer work in Roma communities, institutions, elementary, and high schools. It turned out that most of the Student College members from the interviews were first involved in voluntary work through the Roma Student College. One of them emphasized the importance of voluntary work as a necessary thing to do as a Roma student;" I think I want do voluntary work in places where my presence is needed the most. To show the majority of Gypsy children that they can do it... Because I could do it." (Roma Student College member)

Three-fourth of them would like to do voluntary work in some form even after graduation. The answers reflect that they are committed to volunteering in Roma communities and most of them explicitly formulate their own role for others to follow. This shows that, despite the assimilative resilience of the community, as a positive effect of the Roma Student College, the undertaking, preparation, and imprinting of the role of the translator (model) takes place. This process affects the individual's self-efficacy along the self-help mechanism.

Most of the members of the Roma Student College emphasized that the voluntary work further expands their social network, provides opportunities to develop competences preparing them for the labor market, where they can use the acquired skills.

\section{A consciously pursued vision of future as a component of positive psychology capital}

At the end of the life path interviews, the answers to the question "Where will you be in ten years from now?" are much more specific regarding the professional plans than the personal (residence, family) ideas (Table 6).

This kind of focus is characteristic of students in Higher Education. Relatives of the Student College students who are in in their twenties are typically beginning their careers and families currently. It is therefore especially important to have a supportive community where the Roma Student College members can remind one another of the prioritization needed in long-term education and in the construction of professional careers. This is fundamentally different from the

Table 6. Future plans ( $N: 27)$

\begin{tabular}{lcccccc}
\hline $\begin{array}{l}\text { Mentioned } \\
\text { topics }\end{array}$ & $\begin{array}{c}\text { Work } \\
\text { (specific) }\end{array}$ & $\begin{array}{c}\text { Work } \\
\text { (general) }\end{array}$ & $\begin{array}{c}\text { Family/ } \\
\text { children }\end{array}$ & $\begin{array}{c}\text { Home, } \\
\text { finances }\end{array}$ & $\begin{array}{c}\text { View of the } \\
\text { world }\end{array}$ & $\begin{array}{c}\text { Relation to the } \\
\text { Roma community }\end{array}$ \\
\hline $\begin{array}{l}\text { Number of } \\
\text { people }\end{array}$ & 25 & 2 & 12 & 11 & 9 & 13 \\
\hline
\end{tabular}


social disadvantaged whose survival strategies and internalized feeling of helplessness lead to limited horizons and a culture of "living in the moment". In contrast, the Roma Student College members practice strategies which will lead to broader and more stable development in their future.

Half of the Roma Student College members included activities in or for Roma communities as part of their professional plans, which represents high level of empowerment - and assumes the sustainability of resilience. One-third of the respondents mentioned traveling, seeing the world among their desires ("I would love to. .I don't know. . travel by plane for example", "So I want to quit my life as it is right now and travel the world instead, visit a bunch of places, see how things work there"). This shows that higher education provides a window into the world, but many Roma Student College members have not had the opportunity to cross the border. An important point in most professional plans is the expectation of a secure living, which is included in almost all of the answers. Financial appreciation ("Maybe I will invite you all for something, I don't yet know for what. You all finish much later and I will be working by then, so I can afford these things" - Roma Student College member.) is in most cases closely connected to professional excellence and the desire for appreciation is also a characteristic expression. Supporters who are involved in the course of life, including dedicated teachers, appear in the plans as good examples to follow ("So I imagine myself as a teacher who has a room where we handle business of our own with the students, just like our class teachers, physics and math teachers, used to do" - Roma Student College member). Most of them mentioned that they would stay in touch with other members of the Roma Student College even 10 years from now, because this community has played a significant role in their lives and will continue to for a long time. One of the students said the following; "We will meet occasionally and have, let's say, a seafood pizza or something... There are plans. Even if we drift apart and move to different places in the country, we have plans. Plans together." (Roma Student College member).

The self-consciousness of the Roma Student College members and their profound vision of their future is outstanding. The stories also include the "internal force", which is the "engine" of conscious actions to overcome the difficulties that the assistance of external supporters has also contributed to.

Typically, the longer they have been members of the Roma Student College community, the greater the number of the Roma Student College members turning towards the community (" $A t$ the same time I started to become more active, now that I felt they needed me, I wanted to do things." - Roma Student College member). Their narratives reflect the duality of the community's strength and how they can contribute to the progress of others. Table 7 depicts that the community itself was mentioned 21 times, which is significantly higher than the other elements from the diverse support system of the Roma Student College. The fellow community of the Roma Student College, the self-help mechanism of the members, and the role of the translator, as examples were mentioned in the narratives. Together these create the effective tools for

Table 7. Contribution of the Roma Student College to the implementation of plans ( $N: 27)$

\begin{tabular}{lccccc}
\hline $\begin{array}{l}\text { Topics mentioned } \\
\text { during the interviews }\end{array}$ & $\begin{array}{c}\text { Foreign } \\
\text { language } \\
\text { learning }\end{array}$ & $\begin{array}{c}\text { Motivation } \\
\text { for learning }\end{array}$ & $\begin{array}{c}\text { Intercultural } \\
\text { competence }\end{array}$ & $\begin{array}{c}\text { Financial } \\
\text { support }\end{array}$ & $\begin{array}{c}\text { Community } \\
\text { support }\end{array}$ \\
\hline Number of people & 3 & 15 & 7 & 4 & 21 \\
\hline
\end{tabular}


developing positive psychology capital. One student summarized these ideas with these lines; "But 10 years from now I think I will only talk about the community... many of us have the same interest and there is so much to learn from each other." (Roma Student College member).

\section{CONCLUSION}

We have seen that the members of the Roma Student College, characterized by diversity, are resilient: they are achieving Higher Education, breaking through the difficulties of their family background and the effect of exclusive environments. In their walk of life interviews one can discover the external factors that aimed at the formation of resilience. Most of them reported having supportive families (parents, relatives) and some of them mentioned having role models to follow in their immediate vicinity (siblings, close friends). Many referred to adults (mainly teachers) from their environment (school or organizational), who provided support for progress far beyond the expectations of the school. The strengthened internal characteristics and positive psychological capital help to form a conscious, positive and stable self-image as a counterbalance to the negative effects, could also be observed in the narratives of the Roma Student College members. These positive features were recalled by the narrators through concrete life events and people, often linked to their own, life-changing decisions. In addition, the importance of empowerment for their social integration into the community is clearly acknowledged, which is also reflected in their everyday and future plans, even if in different ways. Reflecting on the Roma Student College, the members emphasized that the college plays a decisive role in their present life. The community power, in which the activities of college students were embedded, was highlighted in the narratives. The creation of community capital has led to the integration of Roma Student College grants as investments in each member and remain so in the forms of personal success (resilience) and social responsibility after completing their higher education. This enables them to become a useful member of society for themselves and their community based on their positive psychological capital.

Ethics: The study procedures were carried out in accordance with the Declaration of Helsinki. The Institutional Review Board of the Institute of Educational Sciences (University of Pécs) approved the study.

Funding sources: No financial support was received for this study.

Authors' contribution: All authors had full access to all data in the study and take responsibility for the integrity of the data and the accuracy of the data analysis. V.A.: study concept and design, data analysis, study supervision. T.F.: data analysis, interpretation of data. V.K: analysis and interpretation of data.

Conflict of interest: The authors declare no conflict of interest.

\section{ACKNOWLEDGEMENTS}

Thank you for the detailed interviews for the members of the Roma Student College. 


\section{ABOUT THE AUTHORS}

Aranka Varga is an assistant Professor at the University of Pécs, Chair of Institute of Education Sciences. Her research interests are theory and practice of inclusion and education of disadvantaged and Roma students. She is a founder and a Leader of an Organization (Student College) which promotes success of Roma students at the University. Nowadays her research focuses on resilience, inclusive excellence and positive psychology.

Fanni Trendl is an assistant Lecturer at the University of Pécs. Her research interests are the practice of inclusion at the higher education and the participation at education of the Roma/ Gypsy students. She is part of a Student College which support Roma/Gypsy students at the University of Pécs.

Kitti Vitéz is an assistant Lecturer at the University of Pécs and a PhD student at the „Education and Society" Doctoral School of Education Programme. Her research field is related to inclusion in higher education, mainly foreign students. She is a Member of the "Inclusive University" project at the University of Pécs and she is a helper of two Student Colleges, which focus especially on Roma and disadvantaged students.

\section{REFERENCES}

Adams, R. (2003). Social work and empowerment. London: Palgrave Macmillan.

Arató, F. \& Varga, A. (Eds.) (2015). Befogadó egyetem - Az akadémiai kiválóság fejlesztése az inklúzió szempontjainak érvényesítésével. Bölcsészettudomány Kar, Neveléstudományi Intézet, Pécs: Pécsi Tudományegyetem.

Arató, F. (2012). Rejtett sztereotípiák az egyetemi hallgatók körében. In: A. Orsós, \& F. Trendl (Eds.), Útjelzők (pp. 24-32). Bölcsészettudományi Kar, Pécs: Pécsi Tudományegyetem.

Asumah, S. N. \& Nagel, M. (2014). Preface. In: S. N. Asumah, \& M. Nagel (Eds.). Diversity, social justice, and inclusive excellence - Transdisciplinary and global perspectives. (pp. 9-13). New York, USA: State University of New York Press, Albany.

Bandura, A. (1998). Personal and collective efficacy in human adaptation and change. In J. G. Adair, D. Belanger, \& K. L. Dion (Eds.), Advances in psychological science: Personal, social and cultural aspects (Vol. 1, pp. 51-71). Hove, UK: Psychology Press.

Bandura, A. (2008). An agentic perspective on positive psychology, In: S. J. Lopez (Ed.), Positive psychology: Exploring the best in people (Vol. 1, pp. 167-196). Wesport, CT: Grrenwood Publising Company.

Bourdieu, P. (1978). A társadalmi egyenlőtlenségek újratermelődése (pp. 268-311). Budapest: Gondolat Kiadó.

Brewer, M. B., \& Weber, J. G. (1994). Self-evaluation effects of interpersonal versus intergroup social comparison. Journal of Personality and Social Psychology, 66, 268-275.

CCIV. (2011). évi törvény a felsőoktatásról.

Ceglédi, T. (2012). Reziliens életutak, avagy a hátrányok ellenére sikeresen kibontakozó iskolai karrier. Szociológiai Szemle, 22(2), 85-110. 
Cserti-Csapó, T., \& Orsós, A. (2013). A mélyszegénységben élők és a cigányok/romák helyzete, esélyegyenlősége. In: Varga Aranka (szerk.), Esélyegyenlőség a mai Magyarországon (pp. 99-120). Pécs: Pécsi Tudományegyetem, Bölcsészettudományi Kar, Neveléstudományi Intézet, Romológia és Nevelésszociológia Tanszék.

Fehérvári, A. (2015). A hátrányos helyzetủ tanulók oktatásának változása. In: Fehérvári Anikó, \& Tomasz Gábor (szerk.). Kudarcok és megoldások - Iskolai hátrányok, lemorzsolódás, problémakezelés (pp. 3152). Budapest: Oktatáskutató és Fejlesztö Intézet.

Forray, R. K. \& Hegedüs, T. A. (2003). Cigányok, iskola, oktatáspolitika, Budapest: Oktatáskutató Intézet Új Mandátum Könyvkiadó.

Forray, R. K. \& Pálmainé, O.A. (2010). Hátrányos helyzetü vagy kulturális kisebbség - cigány programok Educatio 1, 75-87.

Forray, R. K. (2015 ed.). Cigány diákok a felsőoktatásban. Pécs: PTE - WHSz.

Forray, R. K. (2016). Reziliencia a cigány, roma hallgatók körében. In: Oktatás és Fenntarthatóság. HERA

Évkönyvek. Fehérvári Anikó-Juhász Erika-Kiss Virág Ágnes-Kozma Tamás (szerk.). (pp. 171-181). Budapest: Magyar Nevelés-és Oktatáskutatók Egyesülete.

Forray, R. K. (2014). A diploma felé. Cigány diákok a felsőoktatásban. Iskolakultúra, 14(9), 72-85.

Goleman, D. (2002). Érzelmi intelligencia a munkahelyen. Budapest: Edge.

Havas, G., Kemény, I., \& Liskó, I. (2002). Cigány gyerekek az általános iskolában. Budapest: Oktatáskutató Intézet - Új Mandátum Kiadó.

Híves, T. (2015). A hátrányos helyzet területi aspektusai. In: A. Fehérvári, \& G. Tomasz (Eds.). Kudarcok és megoldások - Iskolai hátrányok, lemorzsolódás, problémakezelés. (pp. 17-34). Budapest: Oktatáskutató és Fejlesztő Intézet.

Homoki, A. (2016). A reziliencia recepciója a hazai neveléstudományi kutatásokban. In: G. Pusztai, V. Bocsi, \& T. Ceglédi (szerk.). A felsőoktatás (hozzáadott) értéke (pp. 78-90). Felsőoktatás-Társadalom 6, Nagyvárad-Budapest: Partium Könyvkiadó - Új Mandátum Könyvkiadó.

Jancsák, C. S. (2016). Egy szakkollégium felsőoktatási eredményességhez való hozzájárulása értékszociológiai megközelítésben. In: G. Pusztai, V. Bocsi, \& T. Ceglédi (Eds.). A felsőoktatás (hozzáadott) értéke. (pp. 328-337). Felsőoktatás-Társadalom 6, Nagyvárad-Budapest: Partium Könyvkiadó - Új Mandátum Könyvkiadó.

Jenei, T., \& Kerülő, J. (2016). Perszonális és szociális kompetenciák szakkollégiumi fejlesztése. In: G. Pusztai, V. Bocsi, \& Ceglédi, T. (Eds.). A felsőoktatás (hozzáadott) értéke. (pp. 317-327). FelsőoktatásTársadalom 6, Nagyvárad-Budapest: Partium Könyvkiadó - Új Mandátum Könyvkiadó.

Kemény, I., Janky B., \& Lengyel, G. (2004). A magyarországi cigányság, 1971-2003. Budapest: Gondolat Kiadó, MTA Etnikai-nemzeti Kisebbségkutató Intézet.

Kertesi, G., \& Kézdi, G. (2012). A roma és nem roma tanulók teszteredményei közti különbségekről és a különbségek okairól. Budapest: MTA KRTK KTI - Budapesti Corvinus Egyetem.

Lakatos, K. (2010). A képessé tétel (empowerment) lehetöségei a civil társadalomban. Civil Szemle, 2, 4361.

Liskó, I. (2003). Kudarcok a középfokú iskolában. Kutatás közben, 250. Budapest: Oktatáskutató Intézet.

Luthans, F., Luthans, K. W. \& Luthans, B. C. (2004). Positive psychological capital: Beyond human and social capital (p. 145). Management Department Faculty Publications.

Luthans, F., Youssef, C. M., \& Avolio, B. J. (2007). Psychological capital: Developing the human competitive edge. New York: Oxford University.

Masten, A. S. (2001). Ordinary magic: Resilience processes in development. American Psychologist, 56(3), 227-239. 
Mártonfi, G. (2013). A felmérés néhány tanulsága (Vol. 9-12, pp. 59-67). Új Pedagógiai Szemle 1-2: Szám. Mártonfi, G. (2015). A törvényi változások hatása a hátrányos helyzetü és roma fiatalok iskolázására - A Roma Education Fund számára 2014-15-ben készített kutatás zárótanulmánya (kézirat). Pécs: Pécsi Tudományegyetem, Bölcsészettudományi Kar, Neveléstudományi Intézet.

Masten, A. S., Herbers, J. E., Cutuli, J. J., \& Lafavor, T. L. (2008). Promoting competence and resilience in the school context (pp. 76-84). Professional School Counseling.

Rayman J., \& Varga, A. (2015). Resilience and inclusion. Romology (Vol. 3(10)). Pécs: University of Pécs.

Rosenthal, R., \& Jacobson, L. (1968). Pygmalion in the classroom: Teacher expectation and pupils' intellectual development. New York: Holt, Rinehart \& Winston.

Sebestyén, Z. (2016). Az interszekcionalitás elméleti megközelítései. Metszetek, 2, 108-126.

Seligman, M. E. P. (1998). Learned optimism. New York: Pocket Books.

Smith, E. R., Mackie, D. M., \& Claypool Heather, M. (2016). Szociálpszichológia (pp. 277-329). Budapest: ELTE. Eötvös Kiadó.

Travis, R. Jr. \& Bowman, S. W. (2015). Validation of the individual and community empowerment inventory: A measure of rap music engagement among first-year college students. Journal of Human Behavior in the Social Environment, 25(2), 90-108.

Travis, R. \& Deepak, A. C. (2011). Empowerment in Context: Lessons from hip-hop culture for social work practice. Journal of Ethnic \& Cultural Diversity in Social Work, 20(3), 203-222.

Trendl, F., \& Varga, A. (2018). Tehetséggondozás a roma szakkollégiumban. Romológia 6, 8-33. Évfolyam 2. Szám.

Trendl, F. (2015). A “befogadó környezet” megvalósulása egy egyetemi szakkollégiumban. In: F. Arató, \& A. Varga (Eds.) Befogadó egyetem: Az akadémiai kiválóság fejlesztése az inklúzió szempontjainak érvényesítésével. (pp. 131-139). Pécs: PTE BTK Neveléstudományi Intézet.

Óhidy, A. (2016). A halmozottan hátrányos helyzetből a diplomáig - Tíz roma és cigány nő sikertörténete a magyar oktatási rendszerben. (p. 37). Pécs: Pécsi Tudományegyetem, Bölcsészettudományi Kar, Neveléstudományi Intézet, Romológia és Nevelésszociológia Tanszék. Gypsy Studies - Cigány tanulmányok.

Varga, A. (2015a). Az inklúzió szemlélete és gyakorlata. Pécs: Pécsi Tudományegyetem - WHSz.

Varga, A. (2015b). Esélyegyenlőség és inklúzió az iskolában. In: Varga Aranka (szerk.). A nevelésszociológia alapjai (pp. 241-273). Pécs: Pécsi Tudományegyetem - WHSz.

Varga, A. (2017). Dimensions of equality in a Roma student college Autonomy and Responsibility. Educational Science Journal, 1-4, 31-54. Pécs: Pécsi Tudományegyetem, Bölcsészettudományi Kar, Neveléstudományi Intézet. Online: http://www.kompetenspedagogus.hu/sites/default/files/04autonomia-es-felelosseg-pte-btk-ni-2017-01-04szam.pdf.

Zolnay, J. (2015). A roma diákok esélyei a közoktatásban. In: Orsós Anna. (szerk.). A romológia alapjai. (pp. 249-270). Pécs: Pécsi Tudományegyetem - WHSZ.

Open Access. This is an open-access article distributed under the terms of the Creative Commons Attribution 4.0 International License (https://creativecommons.org/licenses/by/4.0/), which permits unrestricted use, distribution, and reproduction in any medium, provided the original author and source are credited, a link to the CC License is provided, and changes - if any - are indicated. (SID_1) 